\title{
A Rare Cause of Intra Cavernous Internal Carotid Artery Dissection: Sturge Weber Syndrome
}

Olgu Sunumu Case Report

\author{
intrakavernöz internal Karotid Arter Diseksiyonu olan \\ Nadir bir Olgu: Sturge Weber Sendromu
}

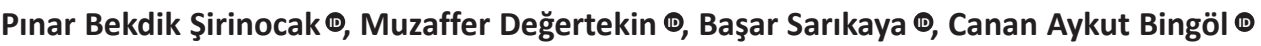 \\ Berrin Aktekin ${ }^{\circledR}$
}

Alındığı tarih: 06.05 .2018

Kabul tarihi: 04.12.2018 Online Yayın tarihi: 29.08.2019

Pınar Bekdik Şirinocak Sağılık Bakanlığı Üniversitesi Kocaeli Derince Eğitim Araştırma Hastanesi, Nöroloji Kliniği, Kocaeli - Türkiye

bekdikpinar@gmail.com ORCID: 0000-0002-4644-6572

M. Değertekin 0000-0002-5343-692X Yeditepe Üniversitesi Tıp Fakültesi, Kardiyoloji Ana Bilim Dalı, Istanbul, Türkiye

B. Sarıkaya 0000-0001-8230-7265 Yeditepe Üniversitesi Tıp Fakültesi, Radyoloji Ana Bilim Dalı, Istanbul, Türkiye

C.A. Bingöl 0000-0002-5044-1870 B. Aktekin 0000-0003-1005-0864 Yeditepe Üniversitesi Tıp Fakültesi, Nöroloji Ana Bilim Dalı, Istanbul, Türkiye

Cite as: Bekdik Şirinocak $P$, Değertekin $M$ Sarıkaya B, Aykut Bingöl C, Aktekin B. A rare Sarlkaya B, Aykut Bingöl C, Aktekin B. A rare
cause of intra cavernous internal carotid artery cause of intra cavernous internal carotid artery Eğit. ve Araşt. Hast. Dergisi. 2019;29(2):20710.

\section{ABSTRACT}

Sturge-Weber syndrome (SWS) is a rare neurocutaneous disease characterized with a port-wine stain and ipsilateral leptomeningeal angiomas. It may cause wide variety of neurological signs and symptoms.

A 63-year-old female patient with a port-wine stain on her face was followed up in our department symptoms of transient ischemic attack and focal epileptic seizures at 2-year intervals.

The investigation of the cause of the transient ischemic attacks showed dissection of the right cavernous internal carotid artery.

To the best of our knowledge, this is the first case in the literature. In advanced age, as in our case, central nervous system involvement could be related to congenital abnormalities of the vascular bed.

Keywords: Sturge-Weber syndrome, dissection, transient ischemic attack, cavernous segment, epilepsy

öz

Sturge Weber sendromu (SWS) porto-şarap lekesi ve ipsilateral leptomeningeal anjiomlar ile karakterize nadir görülen bir nörokütanöz hastalıktır. Çok çeşitli nörolojik belirtilere ve semptomlara neden olabilir.

Yüzünde porto-şarap lekesi olan 63 yaşında kadın hasta bölümümüzde geçici iskemik atak ve fokal epileptik nöbet semptomları ile iki yıl aralıklarla takip edildi. Geçici iskeminin nedeninin araştırılması sırasında sağ kavernöz internal karotis arterin diseksiyonunu gösterildi.

Bildiğimiz kadarıyla, bu literatürdeki ilk olgudur. ileri yașta bizim hastamızda olduğu gibi santral sinir sisteminde vasküler yatağın konjenital anormallikleri ile ilişkili olabilir.

Anahtar kelimeler: Sturge Weber sendromu, diseksiyon, geçici iskemik atak, kavernöz segment, epilepsi

\section{INTRODUCTION}

Encephalo-facial angiomatosis, SWS, exists in the following three types according to the Roach scale: type 1: classical SWS characterized by a portwine stain and leptomeningeal vascular angioma, type 2 exists with the presence of only facial angioma, and type 3 is characterized by leptomeningeal angiomatosis ${ }^{(1)}$.

Sturge-Weber syndrome may present with various neurological clinical signs and symptoms such as transient ischemic attacks (TIAs) and focal seizures. Epileptic seizures are frequently associated with bilateral leptomeningeal lesions, vascular involvement or cortical dysplasia and they may affect individuals at any age. On the other hand, one of the rare causes of TIA is the dissection of the carotid artery, accounting for common at the cervical segment of the carotid bulb ${ }^{(4)}$. In our case, the investi$2 \%$ to $3 \%$ of all strokes ${ }^{(2,3)}$. It is more

(c) Telif hakkı T.C. Sağlık Bakanlığı İmir Tepecik Eğit. ve Araşt. Hastanesi. Logos Tıp Yayıncılık tarafindan yayınlanmaktadır. Bu dergide yayınlanan bütün makaleler Creative Commons Atf-GayriTicari 4.0 Uluslararası Lisansı ile lisanslanmıștır.

(c) Copyright Association of Publication of the T.C. Ministry of Health Izmir Tepecik Education and Research Hospital. This journal published by Logos Medical Publishing. Licenced by Creative Commons Attribution-NonCommercial 4.0 International (CC BY-NC 4.0) 
gation of the cause of the transient ischemic attacks showed dissection of the right cavernous internal carotid artery. To the best of our knowledge, this is the first case in the literature developed in an advanced age as in our case, amnd central nervous system involvement could be related to congenital abnormalities of the vascular bed.

\section{CASE REPORT}

A 63-year-old female patient was first admitted to our clinic in 2013, with a complaint of sudden onset hypoesthesia in the left side of her face and left arm lasting for about five minutes. A week ago, she had been evaluated in another hospital for two of almost the same episodes and put on antiplatelet drug treatment with the diagnosis of TIA. In her first admission to our clinic, she had been experiencing her third attack, her physical and neurological examinations were all within normal limits except a portwine stainon the right side of her face innervated by the second branch of the trigeminal nerve (Figure 1). In her past medical history she had hypertension, mitral valve replacement in 1998, and implantation of permanent cardiac pacemaker in March 2013. Her laboratory analyses were unremarkable except

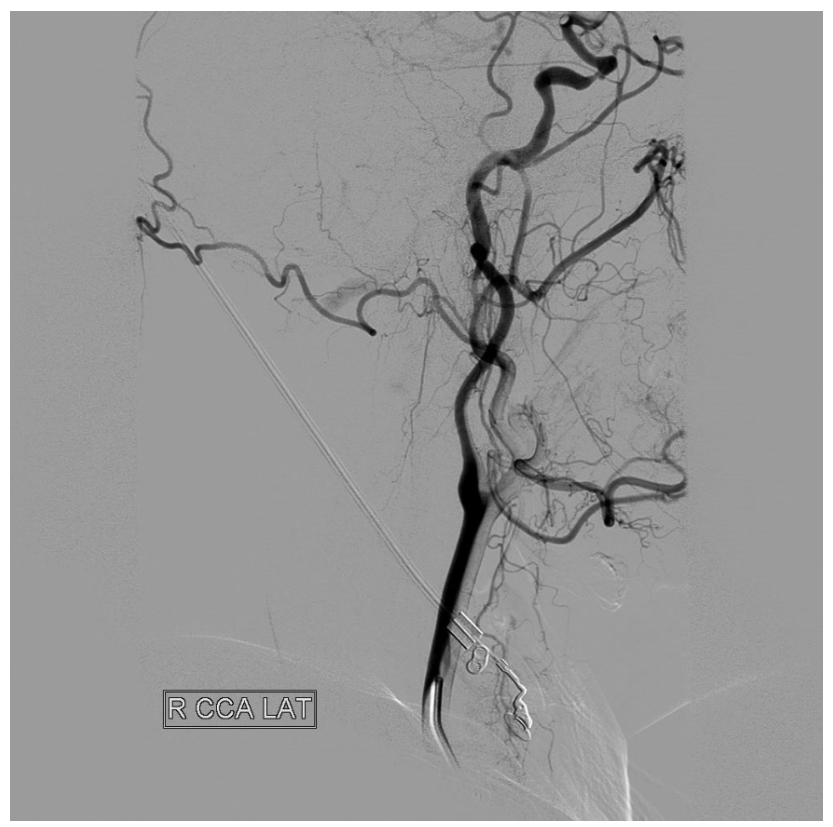

Figure 1. Port-wine stain.

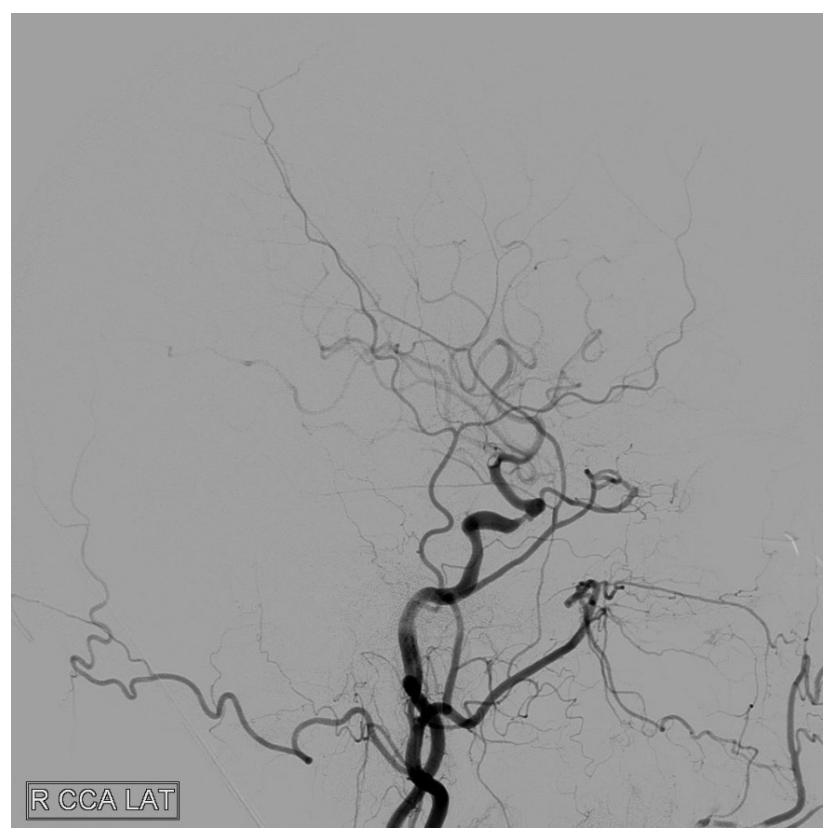

Figure 2. DSA images are in accordance with dissection.

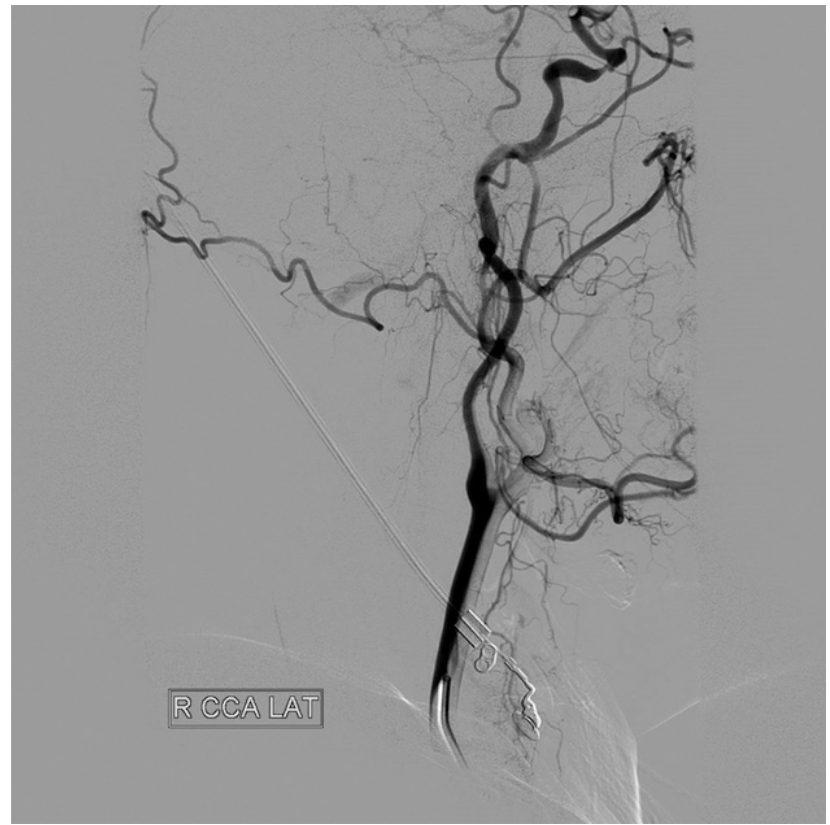

Figure 3. DSA images are in accordance with dissection.

hyperlipidemia. The advanced investigations in cardiology couldn't detect any additional problem. Her cranial magnetic resonance imaging (MRI) with contrast enhancement showed focal narrowing of the right cavernous internal carotid artery, therefore we planned to perform digital subtraction angiography (DSA) of cerebral and cervical vessels. The DSA 
images are in accordance with dissection of carotid artery (Figures 2 and 3). The patient was considered to have TIA caused by dissection of the carotid artery and therapeutic anticoagulation was arranged.

In the course of her regular follow-up, she did not have any other TIA. Meanwhile, six months ago, she presented to our department with episodes of queer epigastric sensation with abdominal discomfort, hot flushes all over her face with profound sweating, hyperventilation and loss of consciousness which lasted for about 1 to 3 minutes then totally resolved within 20 minutes. She was taking sodium warfarin at the time of admission and the INR level was 2.64. In the evaluation of the cardiology department, no cardiac pathology was considered. T2 and flair sequences of the cranial MRI with contrast enhancement showed subcortical areas of nonspecific ischemic gliotic hyperintense signals in both cerebral hemispheres. The interictal EEG showed focal epileptiform activity in the right temporal lobe. Then we diagnosed her episodes as epilepstic seizures and added $500 \mathrm{mg} /$ day levetiracetam to her treatment. The aforementioned attacks didn't appear in her further follow-up.

\section{DISCUSSION}

Sturge-Weber syndrome is a facomatosis characterized with leptomeningeal angiomatosis, port-wine stain and ocular abnormalities ${ }^{(5)}$. Cutaneous portwine mark is the most common capillary vascular malformation existing at an equal frequency in both genders which is $0.3 \%$ in the newborn infants ${ }^{(1)}$. It exists in front of the head on the eyelid, showing localization in accordance with the area innervated by first or second branch of the trigeminal nerve ${ }^{(4)}$. In normal circumstances, the vascular plexus develops at the sixth gestational week and regresses in the ninth week of gestation. Failure of regression results in residual vascular tissue, such as angiomas on face, leptomeninges and the involvement of the ipsilateral eye ${ }^{(6)}$.
Causes of the neurological abnormalities are not clear and the following possible mechanisms have been claimed: hypoxic ischemic damage of the tissue in the side of leptomeningeal capillary venous malformation, decreased cellular glucose metabolism, and cerebral blood flow, venous occlusion and increased venous pressure ${ }^{(1,5,6)}$. The other clinical signs of SWS include epileptic seizures, glaucoma, headache, ischemic cerebral vascular events and behavioral disorders.

TIA has been re-defined in the AHA/ASA guideline in 2009, as the transient neurological dysfunction caused by focal cerebral ischemia which is not related to a permanent cerebral infarct ${ }^{(7)}$. Dissection of the carotid artery is an uncommon cause of stroke, accounting for $2 \%$ to $3 \%$ of all strokes ${ }^{(2,3)}$. It has been reported that dissection of the internal carotid artery causes TIAs in $20 \%$ to $30 \%$ of the patients and cerebral infarct in $40 \%$ to $60 \%$ of them ${ }^{(8,9)}$. Most of the infarcts are embolic in nature and they occur in cortical and subcortical localizations. Patients present with a considerably wide clinical spectrum. It may be asymptomatic, or may exist with headache, pain in the face and neck, tinnitus, Horner syndrome, retinal ischemic events or involvement of the $9^{\text {th }}, 10^{\text {th }}$ and $11^{\text {th }}$ cranial nerves ${ }^{(10)}$. Therefore, it also has a wide spectrum of differential diagnosis. Its etiology has not been fully clarified yet; however, systemic hypertension and arteriopathy are the most frequent causes ${ }^{(4,10)}$. The most common localization of the spontaneous dissection of ICA is $2-3 \mathrm{~cm}$ distal to the cervical segment, towards the carotid bulb (4). Computed tomography angiography, magnetic resonance angiography, and conventional angiography could be use for the diagnosis. In our case, at her first clinical presentation, multimodal neuroimaging did not detect the leptomeningeal angioma and/or calcification but showed arterial dissection, focal narrowing of the right cavernous part of the internal carotid artery as a cause of the transient ischemic attack, detected by DSA. In SWS, dissection of the carotid artery at this localisation has not been previously reported in the literature. 
At the second clinical presentation, our case experienced two episodes with sudden onset, existing with abdominal discomfort which was consistent with an epileptic seizure. EEG recording pointed out to the right temporal epileptic focus. Antiepileptic treatment was initiated and epileptic seizures did not recur. Intracranial abnormalities in SWS may not exist in infants in the early period, and, therefore, re-investigations may be required in the advanced ages. Our case was also re-evaluated for the signs of SWS. T2W flair sequences of the contrast-enhanced cranial MRI revealed subcortical areas of nonspecific signal elevations in both cerebral hemispheres, localized intensively in the frontal areas; however leptomeningeal angioma, cortical dysplasia and calcification did not exist. Although a typical vascular lesion of SWS was not detected in our case, her presentation were considered to be caused by ischemia as a result of dissection of the carotid artery.

\section{CONCLUSION}

In conclusion, SWS is a condition characterized with a port-wine mark, and neurological symptoms caused by leptomeningeal angiomatosis. The patients with port-wine marks present with neurological symptoms should be examined in detail re-garding the SWS. However, even in the advanced ages as in our case, SWS may present with various clinical features such as TIA and seizures due to the cerebral effects caused by a possible congenital anomaly in the vascular bed. Additionally, our case is of utmost importance to highlight the dissection localized at intracavernous segment of the carotid artery, which is a rare cause of the TIA.
Conflict of Interest: There is no conflict of interest between the authors.

Informed Consent: Consent was obtained from the patient.

Çıkar Çatışması: Yazarlar arasında çıkar çatışması yoktur. Hasta Onamı: Hastadan onam alınmıştır.

\section{REFERENCES}

1. Sudarsanam A, Simone L, Ardern-Holmes. Sturge-Weber syndrome: From the past to the present. Eur J PediatrNeurol Soc. 2014;18:257-66. [CrossRef]

2. Schelfaut D, Dhondt E, De Raedt S et al. Carotid artery dissection: three cases and a review of the literature.Eur J Emerg Med. 2012;19:181-7. [CrossRef]

3. Debette S, Leys D. Carotid artery dissections: predisposing factors, diagnosis and outcome. Lancet Neurol. 2009;8:66878. [CrossRef]

4. Flis CM, Jager HR, Sidhu PS. Carotid and vertebral artery dissections: clinical aspects, imaging features and endovascular treatment. EurRadiol.2007; 17: 820-34. [CrossRef]

5. Bodensteiner JB. Sturge-Weber syndrome: review. Up to date. 2015

6. Sanghyi J, Mehta S and Mulye S. Paroxysmal vascular events in Sturge-Weber syndrome: Role of aspirin. J Pediatr Neurosci. 2014;9(1):39-41. [CrossRef]

7. Ross $M$ and Nahab F. Management of transient ischemia attacks in the twenty-first century. Emerg Med Clin N Am. 2009;27:51-69. [CrossRef]

8. Abed K, Misra A and Vankawala V. Spontaneous internal carotid dissection in a 38-year-old woman: a case report. J Com-munityHosplnternMedPerspect. 2015;5(5):10.3402. [CrossRef]

9. Schievink WI, Mokri B and O'fallon WM. Recurrent spontaneous cervical-artery dissection. $N$ Engl J Med. 1994;330:393-7. [CrossRef]

10. Rao AS, Makaroun MS, Marone LK et al. Long-term outcomes of internal carotid artery dissection. J Vasc Surg. 2011;54:370-5. [CrossRef] 